\title{
NATURAL DISASTER AID DISTRIBUTION SYSTEM AND MEETING THE NEEDS OF CASE VICTIMS IN PADANG PARIAMAN REGENCY
}

\author{
"Henny Yulius ${ }^{12}$, Indang Dewata ${ }^{23}$, Heldi $^{24}$ \\ ${ }^{* 1}$ Department of Industrial Engineering, Industrial Technology College of Padang (STTIND) - Indonesia \\ ${ }^{2}$ Doctoral Program of Environmental Science, Postgradute-Universitas Negeri Padang - Indonesia \\ ${ }^{3}$ Department of Chemistry, Universitas Negeri Padang - Indonesia \\ ${ }^{4}$ Department of Fine Arts, Universitas Negeri Padang - Indonesia \\ Email: henny.yulius0101@gmail.com
}

*Corresponding Author, Received: March 8, 2021. Revised: March 21, 2021. Accepted: May 20, 2021

\begin{abstract}
This study aims to determine the fulfillment of the needs of victims of natural disasters through the implementation of a social assistance distribution system for victims of natural disasters that occurred in Padang Pariaman Regency. This research was conducted using a qualitative descriptive approach that describes the social assistance distribution system for victims of natural disasters with an orientation towards meeting the needs of the victims. It can also be categorized as exploratory research which studies a number of cases of aid distribution towards meeting the needs of victims. Data collection was carried out by direct interviews with officials who were directly involved in the distribution of aid, direct observation to victims of natural disasters, document review, and Focus Group Discussion (FGD). Data analysis, using descriptive-qualitative techniques. The results of the study conclude that the current social assistance distribution system for victims of natural disasters has not yet achieved the goal, namely meeting the needs of victims of natural disasters. Long mechanisms and procedures, incompatible with regional conditions, and the absence of potential synergy of personnel are factors between the ineffectiveness of the social assistance distribution system for victims of natural disasters in Padang Pariaman Regency. The results of the study recommend that in formulating a policy for the distribution of social assistance systems for victims of natural disasters, it should begin with periodic mapping of disaster events and the needs of victims, involving victims as recipients of assistance in accordance with the mandate of Article 26 of Law No.24 of 2007 concerning National Disaster Management. Local governments should be given full authority to implement policies in accordance with regional conditions and disaster characteristics. The granting of this authority should be included in the regional autonomy law regarding the rights of regional governments in the case of natural disaster management, specifically included in local regional regulations.
\end{abstract}

Keywords: Aid Distribution System, Natural Disasters, Social Assistance

This work is licensed under the Creative Commons Attribution-ShareAlike 4.0

International License

\section{INTRODUCTION}

The policy for the distribution system for natural disaster relief is essentially oriented towards meeting the needs of the victims. The fulfillment of the needs of victims of natural disasters will be achieved when there is a match between the operation of the distribution system and the characteristics of the area, the characteristics of the disaster, the type of disaster, the number of victims and losses. Based on data compiled by the Regional Disaster Management Agency (BPBD) of Padang Pariaman Regency, it is known that Padang Pariaman Regency is one of the areas with a high level of natural disaster occurrence. From January 2007 to September 2009 in Kabupaten Padang Pariaman there have been eight natural disasters with the following types; landslides, flash floods, whirlwinds and earthquakes. The largest earthquake occurred on September 30, 2009, resulting in significant casualties and material losses. Therefore, this research is focused on distributing aid for victims of the earthquake on September 30, 2009. Law No. 24 of 2007 article 26 (2) mandates that every person affected by a disaster has the right to receive assistance for basic needs. In this context, it is important to pay attention to the fulfillment of victims' needs.

Various policies have been pursued to meet the 
needs of victims, including the enactment of Law No. 24 of 2007 concerning National Disaster Management. Article 48 letter c mandates that the implementation of disaster management is aimed at protecting vulnerable groups, further Law No.11 of 2009 concerning Social Welfare Article 1 paragraph 9 states, social protection is all efforts directed at preventing and managing the risk of shocks. and social vulnerability. The social shock and vulnerability referred to is an unstable situation that occurs suddenly as a result of a situation of social, economic, political, disaster and natural phenomena. The National Plan (Renas) for disaster management for 2010-2014 states that the Ministry of Social Affairs is the main agency determining the policy for the distribution of assistance in meeting basic needs, shelter and psychosocial. This provision has logical consequences for meeting the needs of disaster victims, which are more than just providing assistance but also related to protection. In the government bureaucratic structure, every policy for distributing natural disaster assistance carried out by local governments refers to policies determined by the Ministry of Social Affairs.

The reality is different, when the social assistance distribution system for victims of natural disasters has not been able to run according to the desired goal, namely meeting the needs of victims. Various problems relating to the fulfillment of victims' needs are still happening. Mechanisms, procedures and the synergy of personal potential that have not considered regional potential, regional characteristics, disaster characteristics and socio-economic and cultural conditions of the community are factors that have not fulfilled the needs of victims in a precise, timely and efficient manner.

The level of frequency of natural disasters in Padang Pariaman Regency, the absence of a match between mechanisms, procedures, synergy of personnel potential, disaster characteristics, area conditions, socio-economic and cultural conditions with the fulfillment of victims' needs, are strong reasons for conducting studies. regarding the distribution system of assistance and meeting the needs of victims. The problems raised in this research are: How are the needs of victims of natural disasters fulfilled by implementing a policy for the distribution system of aid for disaster victims? What is the alternative policy for the distribution of aid that must be done? The objective to be achieved is to find out the implementation of the social assistance distribution system for victims of natural disasters in Kabupaten Padang Pariaman in relation to meeting the needs of victims, as well as how the alternative is to implement the policy on the distribution system of social assistance for victims of natural disasters. The results of this research are expected to be a reference material for the Ministry of Social Affairs, local governments and BPBD in developing policies for the distribution of social assistance for victims of natural disasters..

\section{RESEARCH METHODS}

This research can be categorized as exploratory research, with a descriptive-qualitative approach to describe the natural disaster relief distribution system. This research focuses on a number of cases of aid distribution and the fulfillment of the needs of victims of natural disasters. The research location was determined in Padang Pariaman Regency, specifically in the case of the natural disaster on 30 September 2009.

The findings of this study will serve as a basis for recommendations regarding the feasibility of a policy for the distribution of social assistance systems for victims of natural disasters after the enactment of Law No. 24 of 2007 concerning Disaster Management. Sources of data are in the form of information provided by people who know and become direct actors of the distribution of aid to disaster victims, including: BPBD officials, subdistrict officials, village officials, Tagna, TKSK, PSM, as well as information provided by victims directly from natural disasters they experienced. . Data collection is carried out by: 1) Interviews with interview guides as a guide line, aimed at people who have real knowledge of the distribution of aid, as well as disaster victims, 2) Direct observation to victims of natural disasters. 3) Review of documents, especially documents relating to disaster maps, aid distribution systems and victims in various loss gradations; 4) Focus Group Discussion (FGD) with participants from District Social Service officials, sub-district, subdistrict, BPBD, Tagana, TKSK, Karang Taruna, PSM and NGOs. Data analysis, using descriptivequalitative techniques, regarding cases of distribution of social assistance to victims of natural disasters that occurred in Padang Pariaman Regency when the earthquake occurred on 30 September 2009. The results of the research obtained from the empirical realm then become the starting point for reviewing aid distribution system for victims of natural disasters in general, in accordance with the demands of the times.

\section{RESULTS AND DISCUSSION}

\subsection{Area Description in Padang Pariaman Regency}

Padang Pariaman Regency with an area of 1,328.79 $\mathrm{Km} 2$, is divided into 17 Districts, 40 
Nagari, and 366 Korong. The total population in 2010 reached 343,571 people, consisting of 193,472 men and 200,099 women, with a population density of 296 people/km. Judging from the level of education, it is known that: $1,9,752$ people did not/have not graduated from elementary school, a total of 48,002 people have graduated from elementary school, 10,341 people have high school education and above. The total working population is 134,719, consisting of 90,040 men and 44,679 women. Population welfare level; 22,333 people are in a welfare condition, 32,363 people are in prosperous condition I (one), 20,936 people are prosperous II (two), 15,686 people are prosperous III (three), and 1,298 people are prosperous III (three) plus. (Padang Pariaman Social Service 2010).

Land use; Padang Pariaman Regency which has an area of $1,328.79 \mathrm{~km} 2$ is used for plantations, forests and agriculture (rice fields) covering an area of 69.42 percent, and 31.58 percent is used for settlements. In 2009 there were 76,873 housing units, 17,122 units or $22 \%$ of which were unfit for habitation, while 61,651 units or $78 \%$ were in the category of habitable houses. Apart from housing and plantations, the land is also used for road infrastructure along 425,850 meters, 66\% (275,900 m) in damaged condition.

Padang Pariaman Regency is traversed by 11 rivers. The longest river is the Batang Anai River,
$54.6 \mathrm{~km}$ long, and the Batang Mangao River with a length of $46 \mathrm{~km}$. While the shortest rivers are the Batang Kamumuan and Batang Piaman rivers with a river length of $12 \mathrm{~km}$. Economically, these rivers are a support for rice irrigation and fish cultivation which are mostly carried out by the community. Apart from cultivating fish, the rivers are also used for toilets and disposing of garbage which makes this area prone to natural disasters, both floods and landslides. Geologically, Padang Pariaman Regency is located on two fault lines of the world plate, namely the Eurasian plate and the IndoAustralian plate. An earthquake due to shifting of plate faults is very likely to occur followed by a tsunami. Considering the long and sloping coastal area of this area and a subduction zone, Padang Pariaman Regency has the potential to become a disaster area with very severe damage, such as the earthquake that occurred on September 30, 2009 as shown in the description below.

Area Description in Padang Pariaman Regency On September 30, 2009, two earthquakes occurred, the first occurred at $17 ; 18 ; 09$ WIB, with a strength of $7.9 \mathrm{SR}$, a depth of $71 \mathrm{~km}$, the second occurred at $17 ; 38 ; 52$ WIB, with a strength of 6.2 $\mathrm{SR}$, depth $110 \mathrm{~km}$, centered $23 \mathrm{~km}$ southwest of Kota Pariaman and $52.5 \mathrm{~km}$ northwest of Padang City with casualties and damage shown in table 1 below..

Table 1. Description of Victims, Damage to Houses, Public and Social Facilities as a Result of the 30 Sepetember 2009 Earthquake

\begin{tabular}{|c|c|c|c|c|}
\hline No & Type of Demage & Heavy Damage & $\begin{array}{c}\text { Category of Demage } \\
\text { Moderate Damage }\end{array}$ & Slightly Damaged \\
\hline 1 & House & 59.693 units & 16.525 units & 15.148 units \\
\hline \multirow[t]{4}{*}{2} & Public Facilities & & & \\
\hline & a. Office Buildings & 104 units & 32 units & 9 units \\
\hline & b. School Buildng & 257 units & 87 units & 31 units \\
\hline & c. Road/Bridge/Irrigation & 748 units & 225 units & 23 units \\
\hline \multirow[t]{3}{*}{3} & Social Facilities & & & \\
\hline & a. Houses of Worship & 748 units & 255 units & 15 units \\
\hline & b. Orphanage & 2 units & 9 units & 1 units \\
\hline
\end{tabular}

Source: Satlak PB, Padang Pariaman Regency, 2011.

Apart from casualties, damage to housing and agricultural land, other losses include loss of livelihoods and jobs. The earthquake that occurred on September 30, 2009 caused very severe damage in 14 (fourteen) sub-districts and 3 sub-districts with quite severe damage, namely: Batang Anai, Batang Gasan and 2x11 Timber Planting Districts. The earthquake of 30 September 2009, also resulted in the destruction of economic facilities and infrastructure, such as; markets, shops, factories and small industries. The results of interviews with disaster victims obtained information that economic activity in several markets returned to recovery on $\mathrm{D}+7$ after the earthquake. Even so, the community has not been able to optimally utilize the market because the household economy has not yet recovered. 
Table 2. Description of Damage Category to Residential Homes in each District as a result of the Earthquake 30 September 2009

\begin{tabular}{clccc}
\hline \multirow{2}{*}{ No } & & & Home Residents & Ristricts \\
& & R R & RS \\
\hline 1 & Batang Gasan & 361 & 445 & 1.721 \\
2 & Sungai Limau & 981 & 1.095 & 4,538 \\
3 & V Koto Kampung Dalam & 694 & 1.18 & 4.523 \\
4. & IV Koto Aur Malintang & 699 & 1.316 & 3.274 \\
5 & Sungai Geringging & 587 & 1.137 & 5.609 \\
6 & V Koto Timur & 91 & 360 & 4.435 \\
7 & Patamuan & 684 & 1.073 & 2.025 \\
8 & VII Koto Sei Sarik & 989 & 1.913 & 6.278 \\
9 & 2x11 Enam Lingkung & 392 & 811 & 3.265 \\
10 & 2x11 Kayu Tanam & $2 . .409$ & 1.014 & 861 \\
11 & Sintuk Toboh Gadang & 709 & 911 & 2.761 \\
12 & Lubuk Alung & 1.803 & 605 & 5.447 \\
13 & Batang Anai & 2666 & 1.775 & 1.389 \\
14 & Nan Sabaris & 1.001 & 1.384 & 4.011 \\
15 & Ulakan Tapakis & 609 & 692 & 3.864 \\
16 & Padang Sago & 130 & 250 & 2.27 \\
17 & Enam Lingkung & 343 & 564 & 3.557 \\
\hline
\end{tabular}

Source: Satlak PB, Padang Pariaman Regency

The number of houses with the severely damaged category reached 59,693 units. This means that if one house is occupied by 1 household, then 59,693 households in Kabupaten Padang Pariaman are threatened with poverty. The number of poor families increased from 13,718 households ( $16 \%$ from 86,720 households), in 2008 to 27,315 households ( $31 \%$ from 87,408 households) in 2009. In 2010 the number of poor families was 24,522 households or $28 \%$ from 89,424 households.

The increase in the number of poor families occurs in line with the number of other social problems, namely; victims of natural disasters reached 87,905 families, 11,503 cases of neglect, 2,500 cases of disability, 505 cases of socioeconomic prone women. Based on data collected by the Social, Manpower and Transmigration Office in 2011, social problems that stand out as a result of natural disasters are: victims of natural disasters reaching 87,905 families, poor families 24,683 families, neglect 11,503 cases, disability 2,500 cases, women vulnerable to socio-economics 505 cases, RTLH 119 cases, psychological problem families reached 226 cases.

By taking into account the types of disasters and damage that occurred in the earthquake on September 30, 2009, the implementation of the natural disaster relief distribution system policy in the empirical realm is expected to be able to achieve its objectives, namely meeting the needs of victims.

\subsection{Natural Disaster Aid Distribution System in Empirical Studies}

As it is known, the operation of the natural disaster relief distribution system can be seen from the mechanisms, procedures and potential synergies of the personnel implementing the distribution of aid.

1. The mechanism for distributing aid and meeting the needs of victims

The mechanism for distributing logistical assistance and equipment to victims is carried out using the following mechanism. Receipt, logistical assistance and equipment from BNPB, was received and picked up by Satkorlak PB Pro-vinsi West Sumatra at several posts for the arrival of aid, namely at the Governor's Office Post, MinangkaBau International Airport (BIM) and Tabing Airport, Teluk Bayur Seaport, and Bulog Warehouse of West Sumatra Province. The assistance received by Sat-lak PB from the arrival post is administered to be followed up in accordance with the management mechanism. From the results of case tracing it is known that the administrative process must be carried out in order for the assistance to be right on target, in accordance with the needs of the victim and beneficial. The results of interviews with the head of the social assistance division of the District Social Service Office revealed that the aid sent through the airport had often been blocked by the victim before arriving. In the focused discussion, it was revealed that this happened because according to the victim's assessment, the mechanism took too 
long so that the assistance received was not on time.

Storage; assistance was carried out after the PB satlak officer carried out the administrative process by knowing the type of aid items, taking into account the quantity and quality of the relief items, then temporary storage was carried out in the logistics warehouse at the West Sumatra Provincial Governor's Office, and/or distributed directly to the posts under it, namely Districts. The results of interviews with district Social Service officials, obtained information that for the storage of assistance in the form of foodstuffs and equipment from province to district, storage warehouses have not been used in accordance with the storage standards as determined by the Ministry of Social Affairs. For the storage of relief items in the form of foodstuffs and equipment, they still use the space in the Office of Social Affairs, under the supervision of the head of the social assistance sector for an indefinite period. In this condition, the quality of the relief goods will not be maintained. This was admitted by the Head of the Social and Manpower Office of Padang Pariaman Regency who stated that "the storage of relief goods has not been located in a warehouse that meets the requirements for an indefinite period of time. We do not have a warehouse that meets the requirements. " The officers of the Directorate General of Social Protection and Assistance at the Ministry of Social acknowledged that the unavailability of storage for relief goods also stated that in Padang Pariaman District there was no storage warehouse for relief goods, so it became feasible if the relief items became damaged even though they had not expired, or became unfit for use. Damage to goods and expiry of goods results in insufficient fulfillment of the victims' needs, namely hygienic and high quality.

The aid distribution system is a policy, so the availability of adequate building infrastructure is an important thing to pay attention to so that the policy objectives can be achieved. This is in accordance with Edward III's opinion that for the successful implementation of the policy, the availability of resources is needed, including the availability of personnel and on-site infrastructure. Limited resources as a means of supporting the success of policy implementation can also be seen from economic limitations, limited ownership of communication tools and transportation of residents in the disaster area. The results of interviews with urban village officials (Nagari) show that although so far there has been no official data collection on ownership of communication tools and transportation for residents, from the results of observations and confirmation with victims in the affected area it is known that ownership of communication tools is still limited to telephone handhelds and radios, while motorbikes are limited in number.

As a policy, the mechanism adopted is in accordance with applicable regulations. Temporary storage, recording and administrative processes are carried out as a precautionary measure so that assistance can be managed and distributed according to targets in a timely and effective manner. The results of confirmation with the Social Service apparatus of Padang Pariaman Regency obtained information that the distribution mechanism for assistance was from the province. to the district can run smoothly, but in an emergency response the distribution of aid from the district to the sub-district and nagari or korong is slow.

The results of the discussion with the victim obtained information that the delay was not only due to the length of time it had to travel from the district to the affected area, but also because of the damaged road conditions and street lighting equipment. This delay resulted in the unfulfilled needs of victims, both in terms of quality and quantity of relief items. In terms of quality, relief items that have been stored for a long time are likely to be damaged or expired and no longer in accordance with the proper needs of the victims. In terms of quality, it is known that the delay is due to the mismatch between the number of aid items and the number of victims. This is because the number of victims is always increasing and requires recording changes to victim data that are carried out appropriately and quickly. Data collection on the number of victims quickly and accurately requires adequate equipment and professional personnel.

The results of data tracing through interviews with the District apparatus of Nan Saba-ris show that transportation infrastructure, means of communication and personnel prepared for distribution of aid in the sub-districts are very limited. The limited number of personnel and transportation was acknowledged by TKSK, which stated that the number of personal means of transportation was still very limited, they had not been able to reach the disaster location with the level of damage/loss suffered by the victim (4011 houses were severely damaged). Likewise, the communication tools owned by the community are still limited to mobile phones, radio and television.

With regard to the mechanism for the delivery of assistance, the victim acknowledged it as a mechanism with a long bureaucracy, stating; "We only received assistance from the government 7 (seven) days after the disaster." For food purposes, we shared with fellow victims, receiving direct assistance from individuals. The limited number of personnel, the limited ownership of means of transportation and means of communication and 
the distance from the district to the sub-district and the slow mechanisms have resulted in the fulfillment of victims' needs not being carried out in a timely manner.

\section{Procedure for Distribution of Assistance and Meeting the Needs of Victims}

To meet the needs of victims, the logistics assistance distribution procedure was coordinated by Satkorlak/Satlak and carried out in two systems, namely direct distribution based on requests/needs from the sub-district and/or nagari. The procedure is carried out upon request, starting with data collection on the location of the disaster, material losses, number of victims, categories of victims and the needs of victims. In the implementation technique, the distribution procedure is still using the Satkorlak Protap which is carried out with the following procedure: Early information on natural disasters that is obtained from the community is conveyed to Satkorlak PB. Based on this information, Satkorlak followed up by looking directly at the disaster site to conduct an assessment of the impact of the disaster, damage, the number of victims, the needs of victims, the availability of personnel, equipment, disruption to public and government services, the ability of natural resources and resources artificial.

For assistance originating from the government (central and district), both logistics in the form of foodstuffs or equipment are carried out in accordance with the procedure that begins with data collection from korong nagari, in a letter requesting assistance from the sub-district. Delivery to victims is carried out using the same procedure, namely from the Posko district, Nagari/Korong sub-district. This procedure was a letter from the victim who was also the TKSK, as a slow procedure stating "If we had brought it from the district, we would have received the assistance directly".

The mechanisms and procedures for distributing assistance in the District of Pa-dang Pariaman are in accordance with all administrative processes. This can be interpreted positively as a precautionary character of the apparatus/personnel implementing aid distribution. However, the results of confirmation with disaster victims revealed that the mechanisms adopted had resulted in the aid being delivered to the victims not on time or not even according to their needs because during the administrative process, assistance would accumulate in one place at a time which could not be reached. determined, while the needs of the victim are urgent to be met. Such a condition is justified by the Head of the Social Service by stating "Before the relief items are distributed to the victims and during the administrative process, the goods will pile up at the Social Service, this administrative process is important and must be carried out" . The accumulation of relief items somewhere during the administrative process is a consequence and is the compliance of the implementing apparatus towards the policy of the aid distribution system, however in reality this is considered by victims as a slow mechanism and convoluted procedure.

The results of tracing through interviews with victims revealed that in order to obtain assistance, after receiving a letter from the sub-district head, we still had to wait for the administrative process first. In this context, the fulfillment of victims' needs cannot be fulfilled in a timely manner. From the results of interviews with TKSK, Nan Sabaris District, information was obtained that in order to meet the needs of victims, the problem faced was the limited amount of buffer stock. An official from Nan Sabaris District also acknowledged the limitation of the buffer stock, stating that, "the buffer stock is very limited and only exists in the District, while the affected villages are far from the kecamatan. "The limited buffer stock and the distance between the affected sub-district and village (korong) have resulted in uneven or insufficient assistance. Apart from the limited buffer stock, the obstacle to meeting the needs of the victims is due to the limited number of shelters. The limitations of shelters or temporary shelters have made it difficult to collect data on the number and category of victims as well as the number and types of needs of victims, due to the large number of refugee points. The head of the agency acknowledged the limitations of these shelters by stating that the available shelters were still very limited, so that the victims were not well coordinated. The absence of coordination, it was difficult for the organizers of the distribution of aid to meet the needs of victims according to age and sex categories, which indirectly resulted in the unfulfilled needs of victims.

Logistical assistance originating from individuals and/or from caring communities, and sent through Minangkabau Airport cannot be distributed according to procedures because the administrative process has not been carried out, the victim has stopped at the airport. In this condition, the aid received is not evenly distributed, the assistance that should have been delivered at the disaster location is based on existing data, by being blocked, only certain people will receive assistance. The results of the discussion concluded that the victim's desire to get help immediately, a procedure that was considered easier and faster, was a strong reason for the victim to get help by blocking at the airport. In connection with the fulfillment of the victims' needs, a Tagana member who is also a victim who lives in Nan Saba-ris District stated: "Sometimes we cannot receive 
assistance directly, even though we have submitted a request for assistance to the Social Affairs Office with all the requirements". When we asked the officials from the Office of Social Affairs, information was obtained that this was due to the limited potential of personnel distributing aid.

There is also assistance from individuals and/or NGOs that are given without procedure or given directly to victims by coming to the disaster location. One of the victims stated "It is faster and easier for us to get help that is done directly by individuals, because it is without procedures. We only received assistance from the government after 7 (seven) days after the disaster "(disaster victims from Kecamatan Nan Sabaris, H; 5). The assistance provided by donors, whether in the form of foodstuffs or household utensils, was given directly to victims at the disaster site, giving rise to a tendency for assistance to be given to people who were already known. Meanwhile, victims who are not known will only get help out of compassion, not because of rights. The victim considered that the acceptance of assistance from individuals without any procedures would ensure the fulfillment of victims' needs.

\section{Synergism of the Potential of Personnel and Meeting the Needs of Victims}

In the context that victims of natural disasters are people with social welfare problems, the fulfillment of the needs of victims can be achieved if there is a synergy of potential personnel in the mechanisms and procedures. The synergy of potential personnel between the community, NGOs and the government is constitutionally guaranteed by article 38 of Law no. 11 of 2009 concerning Social Welfare. From the results of the FGD, it is known that during the emergency response, almost every korong contained Community Social Institutions (NGOs). However, the large number of Posko NGOs with no time limit and no supervision was considered confusing, because it was difficult for victims to distinguish between government officials and NGOs. The existence of NGOs can be interpreted positively as an effort to facilitate the fulfillment of victims' needs. However, there are many NGOs without clarity about their activities and oversight, so the existence of NGOs is less meaningful than its real purpose. The unclearness of NGO activities was revealed by the victim's statement "We are confused and hesitant to get in touch with NGOs, because we do not understand the activities carried out, they are here indefinitely". In the FGD, the FGD participants suggested that the government supervise NGO activities and set a time limit. In connection with the potential involvement of professional personnel, the Ministry of Social Affairs in collaboration with Dinsosnaker can be seen from the placement of Tagana and TKSK. Padang Pariaman Regency has 38 Tagana and 17 TKSK people. In their orientation, the existence of Tagana and TKSK is intended to provide psychosocial services. However, from the results of the discussion it was known that due to the limited potential of professional personnel, both those owned by the BPBD and the Social Service, at the request of BPBD Tagana often carried out evacuation activities. From this phenomenon, it can be seen that the potential synergy of personnel has occurred, but from the professional aspect and the quantity of potential available personnel, it is not sufficient to fulfill the victim's psychosocial needs.

The results of interviews with Social Service officials showed that to overcome this, the Social Service had collaborated with universities, but the results were not as expected. Children and their parents still need to fulfill their psychosocial needs by providing assistance in an indefinite period of time, while the companion staff for the fulfillment of existing psychosocial needs are limited by time. The results of the search with victims who did not experience psychosocial problems showed that assistance for children and their parents was only carried out for one to three months. Learning from the damage and the number of victims during the earthquake that occurred on September 30, 2009, to meet psychosocial needs, it is necessary to increase the potential synergy of personnel between the community, government and NGOs.

\section{CONCLUSION}

The results of data collection regarding the distribution system for natural disaster assistance and the fulfillment of victims' needs obtained from interviews, observations, FGDs and case analysis can be concluded. The current aid distribution system has not been able to achieve its goals, namely meeting the needs of victims, both logistical, shelter and psychosocial. The victims considered mechanisms and procedures to be a long process, so that the fulfillment of victims' needs was not evenly distributed, even too late and did not match the needs of victims. The application of the distribution system for natural disaster social assistance is not yet in accordance with the condition of the area, the characteristics of the disaster and the potential of the region. The rights of victims to participate in disaster management and distribution of aid as mandated in Article 26 of Law No. 24 of 2007 concerning National Disaster Management have not been implemented properly. 


\section{ACKNOWLEDGEMENTS}

This writing this literature reviews can be carried out smoothly, because of the help and cooperation of various parties. Therefore, the author would like to thank Prof. Dr. Dedi Hermon, MP as the Deputy Director II of the Postgraduate Universitas Negeri (also chairman of the course of disaster risk management, disaster mitigation, and Geography Information Systems/GIS in the Doctoral Program in Environmental Science, Universitas Negeri Padang) who have provided the opportunity and time to sharpen the academic ability my, especially in the field of disaster environmental.

\section{REFERENCES}

[1] Abdul Syahni, 1994. Sosiologi, Skematika,Teori dan Terapan. Jakarta: Bumi Aksara

[2] Alvin L Bertrand.1980. Sosiologi (Terjemahan Sanapiah S. F. ). Jakarta: Bina Aksara.

[3] Ankie M.M. Hoogvelt.1985. Sosiologi Masyara-kat Sedang Berkembang. (disadur oleh Ali-mandan), Jakarta: Rajawali.

[4] Hadari Nawawi Mimi Martini. 1996. PenelitianTerapan. Yogyakarta: Gajah Mada Press

[5] Joko Widodo. 2001. Good Govermance. Telaah dari Dimensi Akuntabilitas dan Kontrol Birokrasi pada Era Desentralisasi dan Otonomi Daerah. Surabaya: Insan Cendekia

[6] Keputusan Menteri Sosial No. 80 Tahun 2010 Tentang Panduan Perencanaan Pembia-yaan Pencapaian Standart Pelayanan Mini-mal (SPM). Bidang Sosial Daerah Provinsi dan Daerah Kabupaten/Kota

[7] Robert MZ Lawang,1985, Buku Materi Pokok Sistem Sosial Indonesia, Jakarta: Karunika.(Universitas Terbuka ).

[8] Sutomo. 2008. Masalah Sosial dan Upaya Pemecahannya. Yogyakarta: Pustaka Pelajar

[9] Moeljarto Tjokrowinoto, dkk. 2001. Birokrasi dalam Polemik. Malang: Pustaka Pelajar Universitas Muhammadiyah.

[10]Tatang M Amirin. 1986. Pokok-pokok Teori Sistem. Jakarta: Rajawali

[11] Winarno Budi. 2002. Teori dan Proses Kebijakan Publik, Yogyakarta: Presindo.

[12] Undang-undang No. 24 Tahun 2007 tentang Penanggulangan Bencana

[13]Undang-undang No. 11 Tahun 2009 tentang Kesejahteraan Sosial. 